\title{
COMMENTS
}

\section{BIG LEAGUE PERESTROIKA? THE IMPLICATIONS OF FRASER $V$. MAJOR LEAGUE SOCCER}

\author{
EDWARD MATHIAS ${ }^{\dagger}$
}

\section{INTRODUCTION}

The filing of an antitrust suit by Major League Soccer ("MLS") players against $\mathrm{MLS}^{1}$ was viewed as a rite of passage for the new league. $^{2}$ After all, every established major professional sports league has been sued for alleged violations of the antitrust laws for practices relating to league rules concerning everything from franchise relocation to the wages of practice squad players. ${ }^{3}$ The importance of Fraser v. MLS for the future of professional sports leagues, however, transcends the continuing legality of the MLS regulations challenged in the suit. Fraser is momentous because it is the first antitrust challenge

† B.A. 1992, Amherst College; M.S. 1997, University of Massachusetts;J.D. Candidate 2000 , University of Pennsylvania. I would like to express my appreciation to Professors Glenn Wong, Lisa Pike Masteralexis, and Edward Rock. I would also like to thank Kirstin Thorne, Bill and Jane Mathias, and Thomas Rapisarda for their support.

'The court adjudicating the lawsuit has already issued one ruling on pre-trial motions made by the litigants. The motions concerned the legality of MLS's transfer fee arrangement with Federacion Internationale de Football Associacion ("FIFA"), the sport's international governing body. The arrangement requires any soccer league seeking to procure the services of a MLS player to pay MLS a fee, even if the player's MLS contract has expired. See Fraser v. Major League Soccer, L.L.C., 7 F.Supp. 2d 73, 79 (D. Mass. 1998) (denying parties' cross-motions for summary judgment regarding MLS's transfer fee rule). The opinion did not address the single entity issue, the pivotal legal issue in the pending litigation and the focus of this Comment.

${ }^{2}$ After hearing of the lawsuit, NBA Commissioner David Stern reportedly told MLS Commissioner Doug Logan, "Congratulations, you've finally arrived." Michael Rosenthal, MLS Raises Expectations, L.A. DAILY NEwS, Mar. 19, 1997, at S4.

${ }^{3}$ See, e.g., Brown v. Pro Football, Inc., 518 U.S. 231 (1996) (defining the extent of the non-statutory labor exemption to antitrust); Flood v. Kuhn, 407 U.S. 258 (1972) (reaffirming baseball's antitrust exemption); NBA v. Williams, 45 F.3d 684 (2d Cir. 1995) (holding that the non-statutory labor exemption to antitrust did not expire when parties engaged in collective bargaining reached impasse); San Francisco Seals v. NHL, 379 F. Supp. 966 (C.D. Cal. 1974) (dismissing a hockey team's antitrust claim against its league). 
to a "single entity league," a league that is organized as a single corporation rather than as a group of individually owned teams. ${ }^{4}$

MLS's single entity structure was designed to insulate the league from one form of antitrust liability under the Sherman Act. ${ }^{5}$ The league is structured as a single corporation, which wholly owns all of the teams that compete in the league. "The Sherman Act contains a 'basic distinction between concerted and independent action." Most antitrust challenges to the established leagues have been brought under section 1 of the Sherman Act ("section 1"), which only applies to concerted action between two economic actors: "It does not reach conduct that is "wholly unilateral." tion are only regulated by section 2 of the Sherman Act ("section 2"), which prohibits monopolization or attempted monopolization of trade. ${ }^{8}$ It is MLS's legal position that, as a single corporation, it cannot "combine, contract, or conspire" with itself, and therefore its internal league practices are not actionable under section 1 . Should the court(s) accept MLS's argument, single entity leagues will have a significant advantage in their labor relations relative to other leagues. ${ }^{9}$ This advantage will encourage newly forming leagues to follow MLS's example and organize as single entities. Perhaps even more significantly, an MLS legal victory may induce more established leagues to reorganize themselves as single entities.

Aside from facilitating the formation of new professional sports leagues, there are no compelling policy reasons for treating MLS as a single entity. Although it may be easy to sympathize with the players' desire to earn what might seem to be their true market value, the players as individual economic entities have little market value. It is only in the context of a competitive league, provided by MLS investors risking millions of dollars in losses, that the players' skills become

\footnotetext{
'See Denise Kiernan, MLS: Living Single?, ThE VILLAGE VoICE, Sept. 30, 1997, at 133 (discussing "MLS's trailblazing single-entity structure").

${ }^{5}$ See PAUl C. WEILER \& GARY R. ROBERTS, SPORTS AND THE LAW 186 (2d ed. 1998) (discussing the reasons MLS structured itself as a single corporation).

${ }^{6}$ Copperweld Corp. v. Independence Tube Corp., 467 U.S. 752, 767 (1984) (quoting Monsanto Co. v. Spray-Rite Serv. Corp., 465 U.S. 752, 761 (1984)).

${ }_{7}^{7}$. at 768 (quoting Albrecht v. Herald Co., 390 U.S. 145, 149 (1968)).

${ }^{8}$ See Sherman Act § 2, 15 U.S.C. § 2 (1994 \& Supp. III 1997) ("Every person who shall monopolize, or attempt to monopolize, or combine or conspire with any other person or persons, to monopolize any part of the trade or commerce among the several States ... shall be deemed guilty of a felony ....").

${ }^{9}$ The players would not be able to bring a section 1 claim against the league, thus removing an important bargaining chip. See discussion infra Part III (discussing the effect of a dismissal of a section 1 claim in light of the low likelihood of success on a section 2 claim).
} 
valuable. Furthermore, although MLS labor restraints may hold down salaries of players already in the league, a profitable league is likely to expand and thus provide employment opportunities for more players.

Despite the lack of policy concerns, the players' suit is significant because it will force the courts to consider how economic coadventurers who retain some minimally disparate economic interests should be treated under the antitrust laws. The courts' response to this question may have a considerable effect on both traditionally organized leagues and non-sports joint ventures that require cooperation among economic competitors.

This Comment explores the implications of a victory for MLS in its current litigation with its players. Part I examines the reasons a professional sports league should be concerned with antitrust law, and the history of the single entity question as it relates to the more "traditional" league model. ${ }^{10}$ Part II compares the various single entity models in existence and analyzes the potential arguments of the Fraser litigants. It concludes, on the strength of its legal arguments, that MLS should be considered a single entity for section 1 purposes, thus rendering intraleague rules immune from section 1 scrutiny. Part III discusses the viability of a claim under section 2 of the Sherman Act against a single entity league, which may limit the extent to which MLS and other single entity leagues are shielded from antitrust scrutiny. Part IV explores the possibility of established, traditionally organized leagues restructuring themselves as single entities and suggests one possible plan to accomplish such a reorganization.

\section{ANTITRUST LAW, PROFESSIONAL SPORTS LEAGUES, AND THE SINGLE ENTITY QUESTION}

\section{A. Antitrust Law}

Antitrust law regulates the conduct of economic actors. Defendants who violate the Sherman Act are liable for treble damages." Therefore, Sherman Act violators may incur enormous liability for their anticompetitive behavior. Section 1 of the Sherman Act prohibits "[e]very contract, combination ... or conspiracy, in the restraint of

${ }^{10}$ The National Football League, National Basketball Association, National Hockey League, and Major League Baseball are all organized similarly. See discussion infra Part I.C (discussing the traditional professional sports league model).

"See 15 U.S.C. $\$ 15$ (1994). 
trade or commerce...."12 The actions of a single economic entity are not subject to section 1 scrutiny because section 1 requires an agreement between at least two independent economic actors, commonly called "concerted action," to satisfy the statute's "contract, combination ... or conspiracy" requirement. ${ }^{13}$ Concerted action is assessed under section 1 under two "complementary categories of antitrust analysis." ${ }^{14}$ Those restraints of trade that have no competitive benefits are declared illegal per se. ${ }^{15}$ Such restraints include price fixing, group boycotts, and horizontal market division. More commonly, restraints are assessed under the rule of reason. Restraints subject to the rule of reason violate section 1 only if the anticompetitive effects of a particular agreement outweigh its procompetitive effects. The competitive effects of these agreements "can only be evaluated by analyzing the facts peculiar to the business, the history of the restraint, and the reasons why it was imposed. ${ }^{.16}$

Section 2 of the Sherman Act applies to single firm conduct as well as concerted action. A firm violates section 2 only when it holds monopoly power in a particular market and engages in behavior that constitutes an abuse of that monopoly power. The requirement that a section 2 defendant possess monopoly power makes a section 2 claim much more difficult to pursue than an action under section 1, which has no such requirement.

\section{B. Why Are Professional Sports Leagues Concermed with Antitrust Law?}

The Supreme Court noted in National Collegiate Athletic Ass' $n v$. Board of Regents that sports leagues and teams require a high level of cooperation among competitors for their product to even exist. ${ }^{17}$ Uniform rules of play, restrictions on scheduling, and myriad other regulations are necessary for college and professional teams to compete on a reasonably level playing field. When sports teams within a league

\footnotetext{
${ }^{12}$ Sherman Act $§ 1,15$ U.S.C. § 1 (1994 \& Supp. III 1997).

${ }^{13}$ Copperweld Corp. v. Independence Tube Corp., 467 U.S. 752, 768 (1984).

"National Soc'y of Prof'l Eng'rs v. United States, 435 U.S. 679, 692 (1978).

${ }^{15}$ See Arizona v. Maricopa County Med. Soc'y, 457 U.S. 332, 344 (1982) (deeming per se treatment appropriate "[o]nce experience with a particular kind of restraint enables the Court to predict with confidence that the rule of reason will condemn it").

${ }^{16}$ National Soc y of Prof'l Eng'rs, 435 U.S. at 692.

${ }^{17} 468$ U.S. 85, 101 (1984) ("When a [hypothetical] league of professional lacrosse teams is formed, it would be pointless to declare their cooperation illegal on the ground that there are no other professional lacrosse teams." (quoting ROBERT H. BORK, THE ANTTTRUST PARADOX 278 (1978))).
} 
agree to certain restrictions, however, they necessarily exclude other potential competitors, suppliers, and distributors of their product. ${ }^{18}$ In other words, the restrictions are agreements in restraint of trade, and, at least facially, violate section 1 of the Sherman Act. ${ }^{19}$

Just as agreements regarding the number of players who may participate on the field of play are necessary to guarantee a level of competitive balance on the field, leagues have attempted to ensure competitive balance by implementing a variety of restrictions that also interfere with players' ability to market their services. The player draft, free agency restrictions, salary caps, and revenue sharing agreements all restrict, to varying degrees, the wages players may earn. The league practices at issue in Fraser are in many ways typical of the type of restraints challenged by players under antitrust law. The standard MLS player contract gives the league the unilateral right to renew the contract, rather than allowing the player to sell his services to the highest bidder. ${ }^{20}$ MLS maintains a salary cap that sets the maximum amount any team may spend on player salaries. This cap is somewhat redundant, however, as a single league official is responsible for negotiating all player contracts and thus has complete control over each team's total salary. ${ }^{21}$ MLS also complies with the transfer fee system created by Federacion Internationale de Football Associacion ("FIFA"), soccer's world governing body, which requires other leagues to pay MLS for the rights to a player, even after the player's contract has expired. ${ }^{22}$

Players' unions regard the threat of an antitrust suit as a significant bargaining tool in negotiations with the leagues. ${ }^{23}$ However, a re-

${ }^{18}$ For example, limiting the number of games that each team plays in a season limits the supply of games that can be broadcast to the public by television networks. Allowing teams to draft particular players limits those players' ability to market themselves in the labor supply market.

${ }^{19}$ The Sherman Act, however, has been interpreted to proscribe only unreasomable restraints of trade. See Standard Oil Co. v. United States, 221 U.S. 1, 60 (1911) ("[I]t was intended that the standard of reason ... be the measure used for the purpose of determining whether in a given case a particular act had or had not brought about the wrong against which the statute provided."); see also State Oil Co. v. Khan, 522 U.S. 3, 10 (1997) ("Although the Sherman Act, by its terms, prohibits every agreement in restraint of trade,' this Court has long recognized that Congress intended to outlaw only unreasonable restraints." (citation omitted)).

${ }^{20}$ See MLS Players' Union Files Suit, Gannett News Service, Feb. 13, 1997, available in 1997 WL 8821935 (describing the standard MLS contract).

${ }^{21}$ See id. (discussing MLS's salary policies).

${ }^{22}$ See id. (discussing the FIFA transfer fee system).

${ }^{23}$ See WEIIER \& ROBERTS, supra note 5, at 204 (noting that other players' unions' inability to achieve their goals through the collective bargaining process led them to pursue, in the alternative, antitrust challenges against their respective leagues). 
cent Supreme Court decision has limited the ability of players represented by unions to sue their respective leagues for antitrust violations. In Brown v. Pro Football, Inc., the Court held that agreements between a multi-employer bargaining unit and a labor union are exempt from antitrust challenge until the "agreement among employers [is] sufficiently distant in time and in circumstances from the collective bargaining process." ${ }^{24}$ It is unclear exactly how long employees must wait after renouncing the collective bargaining process before courts will decide that an agreement meets Brown's "distant in time and circumstance" standard. Nevertheless, an antitrust suit does remain an option for players lacking the bargaining leverage to achieve acceptable hours, wages, and working conditions through the collective bargaining process.

\section{The Traditional Professional Sports League Model}

Four sports leagues have traditionally dominated the national market for team sports: the National Football League ("NFL"), Major League Baseball ("MLB"), the National Basketball Association ("NBA"), and the National Hockey League ("NHL"). ${ }^{25}$ Each of these leagues exists as the product of a contractual agreement among its independently-owned member clubs, which compete against one another in their respective sports. ${ }^{26}$

The member clubs, or franchises, vary widely in how they are organized. A franchise may be organized as a partnership, a privately held corporation, or a publicly traded corporation, among other forms. The leagues themselves are actually unincorporated, nonprofit associations governed by an elected commissioner and an executive committee. ${ }^{27}$ The contract among the franchises sets forth the procedures by which league-wide rules are adopted and enforced, and

${ }^{24} 518$ U.S. 231, 250 (1996).

${ }^{25}$ See WEILER \& ROBERTS, supra note 5, at 468 (discussing "the four historically 'major'sports").

${ }^{26}$ See id. (analyzing the structure of the traditional leagues).

${ }^{27}$ See Gregor Lentze, The Legal Concept of Professional Sports Leagues: The Commissioner and an Altermative Approach from a Comporate Perspective, 6 MARQ. SPORTS L.J. 65, 68-69 (1995) (describing the organization of the four major leagues). As a formal matter, MLB is structured somewhat differently. The organization is divided into the American and National Leagues, both of which are completely independent leagues, each with its own executive power. As a practical matter, however, the American and National Leagues' power is delegated to the Commissioner's office and an Executive Council, similar to the other leagues. See id. at 69. 
delegates powers to the central league office. ${ }^{28}$

\section{Single Entity Theory and the Traditional Sports League Model: Existing Case Law}

The traditionally organized professional sports leagues have long argued that they are in fact single entities, and that their practices are, therefore, not subject to section 1 challenges that various league rules tend to attract. ${ }^{29}$ The leagues "contend that a professional sports league is a unique business, containing an unusual but necessary mixture of interparticipant competition and cooperation not found in any other kind of partnership or joint venture. ${ }^{30}$ Furthermore, they argue that their teams are not competitors in a traditional business sense, but instead are integral parts of a single entity. Although the member clubs may be considered competitors by the public, which focuses on the athletic competition (each league's product), in reality, the actual outcomes of the athletic contests are irrelevant to the business of the league. In the leagues' view, although the teams may compete against one another for a player's services, this competition, like that on the field, is strictly controlled by league rules that are enforced by the central league office, and therefore should be considered an internal business matter. ${ }^{31}$

The traditional leagues' position has received limited judicial approbation. In one early case, San Francisco Seals, Ltd. v. NHL, a federal district court did hold that a professional hockey team could not sue the league in which it competed under section 1 of the Sherman Act. ${ }^{32}$ The Seals court stated that section 1 required "at least two independent business entities" and that in the production of professional hockey games before live audiences in the United States and Canada, "plaintiff and defendants are not competitors in the economic sense." 33

\footnotetext{
${ }^{28}$ See id. at 68-69 (explaining the authority of the leagues' governing bodies).

${ }^{2}$ See supra Part I.B (discussing why sports league rules give rise to antitrust claims).

${ }^{50}$ Michael S. Jacobs, Professional Sports Leagues, Antitmest, and the Single-Entity Theory: A Defense of the Status Quo, 67 IND. L.J. 25, 29 (1991).

${ }^{3}$ See id. at 29, 31-32 (describing the traditional arguments raised by proponents of the single entity defense, and emphasizing the "unique" nature of the intraleague competition).

379 F. Supp. 966 (C.D. Cal. 1974).

ss Id at 969 .
} 


\section{Judicial Rejection of the Seals Approach: Pre-Copperweld Cases}

The single entity defense was rejected by the Second Circuit in North American Soccer League v. NFL, in which the North American Soccer League ("NASL") challenged the NFL's policy of prohibiting football team owners from owning teams in other sports leagues under section 1 of the Sherman Act. ${ }^{34}$ The court concluded that characterizing the NFL as a single entity would create an antitrust "loophole" that could allow the league to adopt restraints to protect individual franchise owners. ${ }^{35}$ The NASL court also emphasized the economic independence of the NFL's franchises:

[E]ach member [club] is a separately owned, discrete legal entity which does not share its expenses, capital expenditures or profits with other members.... [I]n spite of the sharing of some revenues, the financial performance of each team, while related to that of the others, does not, because of the variables in revenues and costs as between member teams, necessarily rise or fall with that of the others. ${ }^{36}$

Arguably, the Second Circuit's rationale values form over substance. Although each team is organized as a separate, independentlyowned entity, the NFL teams could also be viewed as acting as a single corporate board of directors in promulgating the cross-ownership ban. ${ }^{37}$ Additionally, the court understates the economic interdependence of the franchises in stating that the teams share "some" revenues. In fact, when NASL was decided, NFL teams shared $90 \%$ of League revenues. ${ }^{38}$

${ }^{34} 670$ F.2d 1249, 1256-57 (2d Cir. 1982).

${ }^{35}$ See id. at 1257 ("To tolerate such a loophole would permit league members to escape antitrust responsibility for any restraint entered into by them that would benefit their league or enhance their ability to compete even though the benefit would be outweighed by its anticompetitive effects."). This ignores the possibility of a section 2 claim, which has been viewed as a backstop to prevent enterprises from evading antitrust scrutiny altogether. See Standard Oil Co. v. United States, 221 U.S. 1, 60 (1910) ("[A] consideration of the text of the second section serves to establish that it was intended to supplement the first and to make sure that by no possible guise could the public policy embodied in the first section be frustrated or evaded."). As section 2 applies to single firm conduct, sports leagues would still be subject to antitrust law.

${ }^{36}$ North Am. Soccer League, 670 F.2d at 1252.

${ }^{37}$ The Seventh Circuit implicitly adopted this view in Chicago Professional Sports Lld. Partnership v. NBA, 95 F.3d 593, 597-98 (7th Cir. 1996) ("WGN").

${ }^{33}$ See Los Angeles Mem'l Coliseum Comm'n v. NFL, 726 F.2d 1381, 1390 (9th Cir. 1984) ("Raiders") ("[A] large portion of League revenue, approximately $90 \%$, is divided equally among the teams...."). 
Soon after the NASL decision, the Ninth Circuit rejected the single entity defense in a suit brought by the Los Angeles Raiders and the Los Angeles Memorial Coliseum, Los Angeles Memorial Coliseum Commision v. NFL ("Raiders"). ${ }^{39}$ The suit challenged the NFL's efforts to block the Raiders' move from Oakland to Los Angeles. ${ }^{40}$ The Ninth Circuit affirmed the trial court, holding that, as a matter of law, the NFL was not a single entity. ${ }^{11}$ The court based its decision on three main reasons:

Initially, the [district] court recognized the logical extension of [the single entity] argument was to make the League incapable of violating Sherman Act $\$ 1$ in every other subject restriction-yet courts have held the League violated $\S 1$ in other areas. Secondly, other organizations have been found to violate $\S 1$ though their product was "just as unitary ... and requires the same kind of cooperation from the organization's members." Finally, the district court considered the argument to be based upon the false premise that the individual NFL "clubs are not separate business entities whose products have independent value. ${ }^{\text {.12 }}$

First, the court claimed that because other courts had found the League to have violated section 1 , it must therefore be subject to section $1 .^{43}$ The other decisions cited by the court were the NASL case, and three decisions involving NFL rules concerning player contracts: Smith v. Pro Football, Inc., Mackey v. NFL, ${ }^{45}$ and Kapp v. NFL. ${ }^{46}$ The Ninth Circuit's reliance on the latter three cases is extremely questionable. The NFL did not proffer a single entity defense in any of those cases, so those courts simply did not consider the issue. Therefore, the precedents on which the Raiders court relied were not particularly persuasive, even though the aforementioned courts could

${ }^{39}$ See $i d$. at 1390 (affirming the district court's rejection of the NFL's single entity defense).

${ }^{40}$ See id. at 1385 (describing the events preceding the litigation).

${ }^{41}$ See id. at 1387 (holding that, based on the undisputed facts, the district court correctly directed a verdict for the plaintiffs).

Id. at 1387-88 (citations omitted).

${ }^{13}$ See id. at 1388 ("[T] he logical extension of [the single entity] argument was to make the League incapable of violating Sherman Act $\$ 1$ in every other subject restriction-yet courts have held the League violated $\$ 1$ in other areas.").

${ }^{11} 593$ F.2d 1173 (D.C. Cir. 1978) (challenging the legality of the NFL's player selection process, commonly called the draft).

${ }^{45} 543$ F.2d 606 (8th Cir. 1976) (challenging the NFL's rule allowing the league commissioner to require a club acquiring a free agent to compensate the free agent's former club).

${ }^{46} 586$ F.2d 644 (9th Cir. 1978) (challenging, among other things, the legality of the NFL mandate that all players must sign a Standard Players' Contract which binds players to the NFL constitution and bylaws). 
have looked outside the parties' arguments to decide the cases on a single entity-based rationale.

In its discussion of precedent, the Raiders court completely ignored Seals, despite its seemingly direct application to the issue. Instead, the Ninth Circuit relegated the Seals opinion to a footnote in its conclusion and rejected the single entity defense, stating that while Seals was "persuasive," "existing precedent [could not] be ignored." As "existing precedent" in reality consisted of a single Second Circuit opinion, this portion of the Ninth Circuit's reasoning appears to be profoundly unconvincing.

Second, the Raiders court reasoned that the NFL was similar to other businesses shown to be subject to section 1 . The court noted the existence of a Ninth Circuit exception to the finding of concerted action where "'multiple corporations [are] operated as a single entity' when 'corporate policies are set by one individual or by a parent corporation." ${ }^{48}$ The NFL was not covered by this exception, however, because "NFL policies are not set by one individual or parent corporation, but by the separate teams acting jointly." ${ }^{49}$ The Seventh Circuit implicitly rejected this logic in Chicago Professional Sports Ltd. Partnership v. NBA by embracing the "corporate board" analogy, which views the clubs as members of a corporate board controlling league policy. ${ }^{50}$ It is not inaccurate to characterize a league as either "separate teams acting jointly" or as a single firm controlled by a board of directors, which is in part why courts willing to give the single entity argument its due consideration have struggled a great deal to reach a conclusion.

In rendering its holding, the Raiders court cited three well known cases in which concerted action was found even though, as is the case with a professional sports league, cooperation was necessary to produce the product: ${ }^{51}$ Associated Press v. United States, ${ }^{52}$ Broadcast Music, Inc. v. Columbia Broadcast System, Inc., ("BMI") $)^{53}$ and United States v.

${ }^{17}$ Raiders, 726 F.2d at 1390 n.4.

${ }^{48}$ Id. at 1388 (quoting General Bus. Sys. v. North Am. Phillips Corp., 699 F.2d 965, 980 (9th Cir. 1983)).

${ }^{49}$ Id. at 1389.

${ }^{50} 95$ F.3d 593, 597-98 (7th Cir. 1996) (“WGN").

${ }^{51}$ See Raiders, 726 F.2d at 1389 (discussing the relevance of the three cases).

52326 U.S. 1, 14-15 (1945) (holding that the cooperative nature of the enterprise did not make the defendant immune to section 1 liability).

${ }^{53} 441$ U.S. 1 (1979) (applying rule of reason analysis to blanket license offered by license holder of copyrighted songs). 
Sealy, Inc. ${ }^{54}$ Despite the Ninth Circuit's reasoning in Raiders, these cases are actually distinguishable because in each, the defendant independent firm had a viable product that did not require cooperation with competitors, but chose to cooperate with competitors to produce a second product. The cooperation was not necessary to the defendants' core business in those cases, only to the additional joint venture. Members of a professional sports league have no alternative but to cooperate with fellow members. The bedding manufacturers in Sealy, for example, could have simply continued to manufacture their own mattresses rather than form a joint venture with competitors; cooperation was not absolutely essential to the continued vitality of each individual manufacturer's operations. An NFL team, by contrast, has no product to offer if it does not cooperate with others. ${ }^{55}$ It could be argued that the facts of $B M I$ are sufficiently analogous because the inability of individual license holders to protect their rights from infringement made the license essentially worthless by itself; only by combining with other license holders did the license hold value. The $B M I$ court assumed, nevertheless, without discussion, that the groups of individual license holders were combinations for antitrust purposes. ${ }^{56} B M I$ was decided five years before Copperweld, ${ }^{57}$ however, and if the case was reargued in light of Copperweld, it is possible that the court might have accepted a single entity argument.

Third, the Raiders court refused to accept the NFL's argument that its teams were not "separate business entities whose products have an independent value." ${ }^{38}$ The court discounted the cooperation necessary to produce a football game because a team could play outside of the league. ${ }^{59}$ The value of such an undertaking, however, especially over the long term, is so small in proportion to the value realized by a team competing in the NFL that it makes the court's argument entirely unconvincing. ${ }^{60}$ Although the court's independent

${ }^{54} 388$ U.S. 350 (1967) (finding that the joint venture among bedding manufacturers violated section 1 ).

${ }^{55}$ As the Seventh Circuit noted in WGN, "a league with one team would be like one hand clapping." WGN, 95 F.3d at 598-99.

${ }^{56}$ See BMI, 441 U.S. at 7-9.

${ }^{57}$ Copperweld Corp. v. Independence Tube Corp., 467 U.S. 752 (1984); see supra text accompanying notes $62-64$.

${ }^{53}$ Raiders, 726 F.2d at 1388 (citation omitted).

${ }^{59}$ See id. at 1390 (arguing that teams could play outside of the NFL).

${ }^{\infty}$ The NFL's Washington Redskins were recently sold for a reported $\$ 800$ million. See Adrienne T. Washington, Bully Turns Benefactor in $\$ 800$ Million Stroke, WASH. TIMES, Jan. 12, 1999, at C2 (discussing the sale of the team). If the Redskins had announced before the sale of the franchise that the team would no longer compete in the NFL, 
value claim is somewhat understandable given the existence at the time of the United States Football League, which a NFL team could theoretically have joined, the likelihood of such a defection in reality was extremely small. ${ }^{61} \quad$ By contrast, the independent value of the products made by the defendants in Associated Press, BMI, and Sealy were not based on a court's whimsical speculation, but instead on their demonstrated performance in the marketplace. Therefore, such a comparison is inappropriate.

\section{Copperweld Corp. v. Independence Tube Corp.}

Soon after the Ninth Circuit's decision in Raiders, the Supreme Court issued a factually distinguishable decision that nonetheless could be viewed as supporting the NFL's single entity argument. In Copperweld Corp. v. Independence Tube Corp., the Court overturned the intra-enterprise conspiracy doctrine, which provided that agreements within corporations, usually between a parent corporation and its subsidiary, satisfied the section 1 conspiracy requirement. ${ }^{62}$ Instead, the Copperweld Court held that a parent corporation and its wholly owned subsidiaries constituted a single firm for antitrust purposes and were thus exempt from section $1 .^{63}$ The Court's approach to the concerted action requirement discounted the importance of an entity's economic form, and instead instructed courts to look at the economic reality of the business's structure. ${ }^{64}$ To proponents of the professional league's single entity argument, this new emphasis on reality over form urged a reconsideration of the single entity claim.

\section{Post-Copperweld Case Law}

In the wake of the Copperweld decision, however, the courts have generally followed Raiders and distinguished Copperweld, rather than finding Copperweld sufficiently analogous to dismiss section 1 claims

but would instead arrange exhibition games with whatever teams they could schedule, the team's value would have plummeted.

${ }^{61}$ The failure of any team in one of the four major professional leagues to defect to another league speaks to the economic irrationality of such a move.

${ }^{62} 467$ U.S. 752, $772-73$ (1984) ("Because there is nothing inherently anticompetitive about a corporation's decision to create a subsidiary, the intra-enterprise conspiracy doctrine "imposes grave legal consequences upon organizational distinctions that are of de minimis meaning and effect." ) (citations omitted).

${ }^{63}$ See Copperweld, 467 U.S. at 776 (" [W] can only conclude that the coordinated behavior of a parent and its wholly owned subsidiary falls outside the reach of [section 1].").

${ }^{64}$ See id. at 772 (rejecting the intra-enterprise conspiracy doctrine because it "looks to the form of an enterprise's structure and ignores the reality"). 
against the professional leagues. In Sullivan v. NFL, the First Circuit stated that "the critical inquiry is whether the alleged antitrust conspirators have a 'unity of interests' or whether, instead, 'any of the defendants has pursued interests diverse from those of the cooperative itself." "65 The Sullivan court found that NFL teams compete with one another "for things like fan support, players, coaches, ticket sales, local broadcast revenues, and the sale of team paraphernalia. ${ }^{.66}$ Due to the existence of this off-field competition, the teams did have "diverse interests," and thus failed the latter part of the "unity of interests" standard. ${ }^{67}$ As a result, the Sullivan court held that NFL teams were not a single entity for section 1 purposes. ${ }^{68}$

The Sullivan court purported to adopt the standard for interpreting Copperweld set forth in City of Mt. Pleasant v. Associated Electric Cooperative, Inc. ("Mt. Pleasant"). ${ }^{99}$ In Mt. Pleasant, a joint venture that supplied electricity to rural communities was found by the court to be a single entity. ${ }^{70}$ The Associate Electric Cooperative featured an elaborate three-tiered ownership structure. It was owned by six generation and transmission cooperatives, which in turn were owned by fortythree distribution companies. These distribution companies' customers-425,000 individual consumers-owned the distribution companies. $^{\text {"I }}$ Therefore, the decision-making power within the Cooperative was, as a formal matter, diffused widely among a variety of separately owned economic entities.

Although the First Circuit in Sullivan and the Eighth Circuit in Mt. Pleasant agreed on the same legal standard to use, they applied that

${ }^{65} 34$ F.3d 1091, 1099 (1st Cir. 1994) (quoting City of Mt. Pleasant v. Associated Elec. Coop., Inc., 838 F.2d 268, 274-77 (8th Cir. 1988)). This approach was criticized by the Seventh Circuit in WGN:

Although [the complete unity of interests] phrase appears in Copperweld, the Court offered it as a statement of fact about the parent-subsidiary relation, not as a proposition of law about the limits of permissible cooperation. As a proposition of law, it would be silly. Even a single firm contains many competing interests.

Chicago Profl Sports Ltd. Partnership v. NBA, 95 F.3d 593, 598 (7th Cir. 1996) ("WGN").

${ }_{66}^{6}$ Sullivan, 34 F.3d at 1098.

${ }^{67}$ See id. at 1099 ("NFL member clubs compete in several ways off the field, which itself tends to show that the teams pursue diverse interests and thus are not a single enterprise under $\S 1 . ")$.

${ }^{\in} \mathrm{Id}$.

${ }^{69}$ Mt. Pleasant, 838 F.2d 268 (8th Cir. 1988).

${ }^{70} \mathrm{Id}$.

"See id. at 271 (describing the complicated ownership and supply structure of the cooperative). 
standard in very different ways. Much like the plaintiff in Sullivan, the petitioner in Mt. Pleasant argued that the cooperative members had diverse economic interests because they competed for customers, including municipal customers, were forced to arbitrate a dispute concerning rate structures, and disagreed over how to divide the cooperative's profits. ${ }^{72}$ The court found that this evidence proved that the cooperative members had diverse economic interests, but "not in the sense necessary to create a fact issue on whether these companies are part of a single enterprise. ${ }^{\text {73 }}$ The Mt. Pleasant court's discussion of the intracooperative competition is notable because it focused much more on the overall purpose of the cooperative rather than on certain areas in which cooperative members competed.

Even though the cooperatives may quarrel among themselves on how to divide the spoils of their economic power, it cannot reasonably be said that they are independent sources of that power. Their power depends, and has always depended, on the cooperation among themselves.... The disagreements we have described are more like those among the board members of a single enterprise, than those among enterprises which are themselves separate and independent. ${ }^{74}$

This analysis, when applied to a professional sports league, seems to support a finding of single entity status. The NFL owners do function like "board members of a single enterprise" when they promulgate the league-wide rules that are at issue in antitrust claims against the League. ${ }^{75}$ In addition, the League's economic success "depends, and has always depended, on the cooperation among [the member teams]. ${ }^{36}$ In light of this language, and more significantly, the overall reluctance of the $M t$. Pleasant court to accept evidence of intracooperative competition so as to create even an issue of fact, it is clear that the Sullivan court interpreted Copperweld very differently than the $M t$. Pleasant court. Furthermore, it seems clear that an Eighth Circuit court dutifully following Mt. Pleasant would have no choice but to hold

${ }^{72} I d$. at 276-77. In addition, the city argued that the cooperative members must have competed in the labor market, see id. at 277 , a factor the Sullivan court found very persuasive in ruling that the NFL failed to meet the unity of interests standard, see Sullivan, 34 F.3d at 1098-99.

${ }^{73}$ Mt. Pleasant, 838 F.2d at 277 . The procedural posture of this case further points to the difference between the standards of the First and the Eighth Circuits. The $M t$. Pleasant petitioners merely had to show that there was a triable issue of fact regarding the diversity of the cooperative members' interests. $I d$.

\footnotetext{
${ }^{21} I d$.

${ }^{75} \mathrm{Id}$.

${ }^{76} I d$.
} 
that a professional sports league is a single entity.

Nevertheless, in an unpublished opinion, a district court in the Eighth Circuit reached the same outcome as the Sullivan court by applying a different legal principle. In reviewing that trial court's decision, the Eighth Circuit in St. Louis Convention $\mathcal{E}$ Visitors Commission $v$. NFL noted that the district court found that the league was estopped from arguing that its teams comprised a single economic entity because of the Ninth Circuit decision in Raiders. ${ }^{77}$ The trial court also found that neither Copperweld nor Mt. Pleasant necessitated that it reconsider the league's single entity argument. ${ }^{78}$ The district court did dismiss the case during the course of the trial, however, because of insufficient evidence. ${ }^{79}$ The Eighth Circuit affirmed the trial court's dismissal, and therefore did not address the NFL's cross-appeal on the single entity question. ${ }^{80}$

Much of the leading case law demonstrates the courts' hostility to the single entity argument, but a Seventh Circuit case, Chicago Professional Sports Ltd. Partnership v. NBA ("WGN"), suggests that the majority view has not necessarily gained a consensus and that the single entity question with regard to traditionally organized sports leagues remains an undecided one. ${ }^{81}$ In WGN, the trial court ruled that the NBA was not a single entity because its teams did not have a "complete unity of interest. ${ }^{82}$ The Seventh Circuit vacated that holding and remanded the case for further consideration. ${ }^{83}$ The Seventh Circuit agreed with. the trial court's holding that NBA teams did not have a "complete

T 154 F.3d 851, 856 (8th Cir. 1998) (recounting the trial court's findings).

${ }^{73}$ See id. ("The district court was not persuaded that two subsequent cases [(Copperweld and Mt. Pleasant)] dealing with the concept of single economic enterprise required a different result.").

${ }^{79}$ See id. at 859 ("Since the court concluded that [the plaintiff] had presented no evidence to show that the NFL's rule and the guidelines actually had caused league teams other than the Rams to refrain from competitive bidding on the Trans World Dome lease, it granted the Rule 50 motion.").

${ }^{80}$ See id. at $865 \mathrm{n} .9$ (dismissing the NFL's cross-appeal of the trial court's single entity ruling).

95 F.3d 593 (7th Cir. 1996).

${ }^{82}$ Id. at 597 . The case involved a dispute between the plaintiffs, the Chicago Bulls basketball team and WGN, a cable television station, and the defendant NBA, over how many Bulls games WGN was permitted to broadcast each basketball season. See id. at 595 (explaining that both sides have appealed the trial court's 30 game allowance, with the Bulls and WGN wanting to broadcast 41 games per year, and the NBA seeking to fix the number between 15 to 20). The league argued that the broadcasts infringed on the rights of other cable stations that had contracted with the NBA for rights to televise games nationally.

${ }^{83}$ See id. at 601 (vacating the district court's judgment of "all events" and remanding). 
unity of interest," but held that such a determination was not necessarily dispositive of the single entity question. ${ }^{84}$ The court did not interpret Copperweld to "hold that only conflict-free enterprises may be treated as single entities." ${ }^{85}$ After all, the court noted, "multi-stage" firms such as General Motors or IBM often have conflicts between various departments. ${ }^{86}$ According to the WGN court, Copperweld held that the concerted action requirement exists to scrutinize "[c]onduct that 'deprives the marketplace of the independent centers of decisionmaking that competition assumes." subsidiary relationship did not deprive the marketplace and, therefore, was not subject to section 1 scrutiny.

Applying this interpretation, the Seventh Circuit stated that " $[w] e$ see no reason why a sports league cannot be treated as a single firm in this typology. ${ }^{88}$ The court stopped short, however, of declaring the NBA a single entity. In remanding the case, the court stated that the single entity question requires a fact-specific inquiry into the nature of the league. The WGN court argued that it is entirely possible for one league (the NBA, for example) to be characterized as a single entity and for another league (the NHL, for example) to be subject to the Rule of Reason. ${ }^{89}$ Furthermore, separate aspects of league decisionmaking may be characterized differently. The WGN court stated:

[W] do not rule out the possibility that an organization such as the NBA is best understood as one firm when selling broadcast rights to a network in competition with a thousand other producers of entertainment, but is best understood as a joint venture when curtailing competition for players who have few other market opportunities. ${ }^{90}$

The standard set forth by the WGN court effectively articulates why the single entity question is so difficult, but fails to answer satisfactorily how professional sports leagues ought to be characterized. The "depriving the marketplace of independent centers of decision-making" standard fails to give much guidance to the trial courts that must actually make such determinations. Furthermore, it requires in each in-

\footnotetext{
${ }^{84}$ Id. at 598.

${ }^{85} \mathrm{Id}$.

${ }^{86} \mathrm{Id}$.

${ }^{87}$ Id. (quoting Copperweld Corp. v. Independence Tube Corp., 467 U.S. 752, 769 (1984)).

${ }^{83} I d$.

${ }^{89}$ See id. at 600 ("Sports are sufficiently diverse that it is essential to investigate their organization and ask Copperweld's functional question one league at a time ....").

${ }^{90}$ Id.
} 
stance a fact-intensive review of the facets of a league's operation, as well as comparison with other leagues and other business forms, to reach a conclusion. These requirements, therefore, deny all parties the efficiency benefits of a bright-line rule. An inquiry of this sort has not yet taken place, as the parties in WGN reached a settlement after the Seventh Circuit's decision was rendered. ${ }^{91}$

A review of the case law concerning the traditional leagues' single entity argument shows a prevailing hostility to the leagues' claim that they constitute single economic units for antitrust purposes. Courts have consistently followed the result reached by the court in Raiders, notwithstanding the questionable rationale behind that decision. The Seventh Circuit's WGN decision suggests, however, that the rule of Raiders has not been universally accepted. The parameters of the debate will undoubtedly influence the Fraser court's reasoning in affirming or denying MLS's single entity claim.

\section{THE NEW PARADIGM: SINGLE ENTITY LEAGUES}

The existing case law on the single entity question discussed in Part I.C only directly applies to leagues organized according to the traditional model as described in Part I.A. Partly in response to the courts' generally hostile reaction to the established leagues' single entity arguments, several upstart leagues have organized themselves as single corporate entities. ${ }^{92}$ Before evaluating the legal arguments available to the litigants in Fraser $v$. MLS, it seems appropriate to heed the Seventh Circuit's admonition, ${ }^{93}$ and examine the nature and practices of the league at issue, and compare its structure to those of fellow single entity leagues.

\section{A. Benefits of a Single Entity League}

Given the history of repeated antitrust challenges to the traditional league practices described in Part I.B, any protection the leagues can muster from antitrust scrutiny would benefit them considerably. If the leagues are viewed as single entities, they could avoid the potential of treble damages as well as the costs of litigation from

${ }^{91}$ See Lacy J. Banks, Fans Big Winners in NBA-WGN Settlement, GHICAGo SUN-TIMES, Dec. 15, 1996, at 7 (describing the effects of the settlement).

${ }^{92}$ See infra Part II.A (discussing leagues organized as single entities).

${ }^{93}$ See supra notes 81-90 and accompanying text (discussing the Seventh Circuit's decision in WGN). 
suits arising under section 1 of the Sherman Act. ${ }^{94}$ Potential plaintiffs would be forced to challenge league rules as abuses of monopoly power under section 2 of the Sherman Act, a far more difficult claim to prove. ${ }^{95}$ The league would thus enhance its bargaining leverage over its players' union because the union would be unable to threaten the league with a section 1 lawsuit. ${ }^{96}$ The corporate structure of the league would offer other advantages as well. The league can increase the value of its sponsorship agreements by ensuring its league-wide sponsors that individual clubs will not enter into sponsorship agreements with competitor firms that dilute the value of the league-wide sponsor's investment. ${ }^{97}$ The corporate league can also reduce the number of decisions that require building a consensus among league owners. By contracting to place league decision-making power in the hands of the central league office, the corporate league can prevent franchises from relocating, realign divisions, and otherwise make decisions that serve the purposes of the league as a whole rather than individual owners. ${ }^{98}$ Finally, the league can achieve economies of scale through increased purchasing power. ${ }^{99}$

\section{B. Organization of Major League Soccer}

MLS was initially designed by Los Angeles attorney Alan Rothen-

94 The Sherman Act provides that successful plaintiffs may recover three times the amount of their actual damages. See 15 U.S.C. $\$ 15$ (1994).

${ }_{95}$ See infra Part III (discussing section 2 liability).

${ }^{96}$ Although the leagues are protected from antitrust challenges by players' unions under the non-statutory labor exemption, see WEILER \& ROBERTS, supra note 5, at 204, it remains possible that a union could decertify and individual players, "sufficiently distant in time and circumstance" from the collective bargaining process, could bring suit against a league. See Brown v. Pro Football, Inc., 518 U.S. 231, 250 (1996) (holding that federal labor laws shield from antitrust attack an agreement among several employers bargaining together to implement the terms of their last best good-faith wage offer, after reaching an impasse in bargaining with the players' union). In McNeil v. NFL, 790 F. Supp. 871 (D. Minn. 1992), the National Football League Players Association decertified in order to bring suit against the NFL to challenge the League's "Plan $B^{\prime}$ free agency rules, which ultimately resulted in a settlement that dramatically increased the players' freedom of movement.

${ }_{97}$ See Larry Lebowitz, Sports Inc.: Leagues Are Forming As "Single Entities" Where Decision and Profits Are Shared By All Owners, SUN-SENTINEL (Fort Lauderdale), Apr. 20, 1997, at IF (noting that the owners of the Dallas Cowboys and the New York Yankees have signed sponsorship deals with companies that compete with official league-wide sponsors).

${ }^{98}$ See id. (explaining that the single entity model protects a league from the whims and over-spending of an individual owner).

${ }_{99}$ See id. (discussing how "single-entity ownership create[s] a lot of advantages in negotiating broadcast rights and sponsorship deals"). 
berg as a limited-liability Delaware corporation run by a Board of Directors appointed by league investors. ${ }^{100}$ Rothenberg planned that MLS would own and operate all of the teams in the league, assign players and team personnel, and set local ticket and concession prices. League investors would merely own shares in MLS itself. ${ }^{101}$ This structure effectively addressed the reasoning of the Sullivan court, which rejected the NFL's single entity defense because NFL teams compete off-field, ${ }^{102}$ by simply eliminating all forms of off-field competition. The only competition possible in this model is in the form of the onfield games themselves. In MLS's view, the games do not represent competition in any economic sense, but rather represent the product of the MLS corporation. It seems highly likely, therefore, that if MLS had retained this structure, the players' section 1 claims in Fraser would have been dismissed under Copperweld. ${ }^{103}$

MLS was forced to modify its structure before it began operating, however, when it had difficulty attracting investors. Potential investors were discouraged from investing by the anonymity of their roles and preferred to be more involved in running a team. ${ }^{104}$ Under the new arrangement, MLS retained formal ownership of its franchises but issued a special class of stock to "investor-operators." This special class of stock gave them "almost full operating control" over the management of a particular franchise. ${ }^{105}$ The franchises and the league equally share local revenues (generated by the teams from ticket sales, concessions, signage, etc.), while MLS retains all national television and merchandising revenues. The funds MLS receives are used in part to pay all player salaries. The investor-operators receive dividends on profits from league operations and may also sell their special stock to outside groups, just as in traditional leagues. ${ }^{106}$ In this new structure, MLS teams do compete with each other in some of the same ways noted by the Sullivan court. Thus, the new structure is clearly a less "pure" single entity than the MLS Rothenberg originally envisioned, and somewhat more like traditionally organized leagues. ${ }^{107}$

${ }^{100}$ See WEILER \& ROBERTS, supra note 5, at 495-96 (discussing MLS's original design).

${ }_{101}$ See id. (detailing MLS's original structure).

${ }^{102}$ See supra text accompanying notes 65-68 (discussing the Sullivan decision).

${ }^{103}$ See WEMER \& ROBERTS, supra note 5, at 497 (describing the outcome as "almost certain").

${ }_{105}^{104}$ See id. at 496 (explaining why MLS initially had problems attracting investors).

${ }^{105} \mathrm{Id}$.

${ }^{106}$ See id. at 496 (setting forth the details of MLS's current organization).

${ }^{107}$ The structures of two other recently formed single entity sports leagues show the extent to which the structures of single entity leagues can differ. The American Bas- 
There is another extremely important structural difference between MLS and the traditional leagues, however, which tempers intraleague competition and thus complicates application of the Sullivan court's standard to MLS. MLS allows its investor-operators to run more than one team. In fact, three individual investors manage a total of seven teams, more than half of the twelve teams currently competing in MLS. ${ }^{108}$ The players and coaches selected by the MLS investor-operators with multiple teams are thus more accurately described as "allocated" to a particular team. Overall, intraleague competition is substantially foreclosed because so many teams share common investor-operators. ${ }^{109}$ The prospect of the vigorous off-field competition found by the Sullivan court is highly unlikely because of the potential

ketball League ("ABL"), which has since suspended operations and declared bankruptcy, originally consisted of eight teams. See Amy Shipley, ABL Says It Is Bankrupt and Shuts Dowm, WASH. POST, Dec. 23, 1998, at DI (reporting the ABL's announcement that it was suspending operations). Both the players and management of each team were employed and allocated to individual teams by the league office. In addition, the players were given a $10 \%$ interest in the ABL. See WEILER \& ROBERTS, supra note 5, at 497-98 (describing the ABL's corporate tructure). The Women's National Basketball Association ("WNBA") could be characterized as a "less pure" single entity than the ABL. The WNBA LLC (limited liability company) is a corporation owned by NBA Development, which in turn is owned by the 29 NBA franchises, each of which has different owners. See id. at 497 (discussing the WNBA's structure). The NBA teams have official control of the WNBA, but a board of eight NBA owners and the NBA commissioner sets WNBA policy. The WNBA, like the ABL, hires both players and coaches, and assigns them to individual teams. The NBA teams who play in the same city as WNBA teams manage the franchises and receive a share of local revenues generated by the team. See id. (contrasting the ABL and the WNBA). Since the WNBA players have chosen to form a union and begin bargaining with WNBA management rather than pursue litigation like the MLS players, it is unlikely that a decision regarding application of section 1 to the WNBA is imminent. See W.H. Stickney, Jr., WNBA Athletes Vote to Affiliate with NBA Players' Union, HOUSTON CHRON., Nov. 6, 1998, at 2 (discussing the results of the vote certifying the National Basketball Players Association as the WNBA players' official bargaining representative).

${ }^{10 s}$ See Michael Hiestand, A Family That Plays Together, USA TODAY, Dec. 2, 1998, at 3C (noting this apparent conflict of interest). Robert Kraft and Lamar Hunt, both of whom also own NFL franchises, operate two franchises each. See id. (asserting that three owners control a majority of the franchise's teams). Phillip Anschutz, a part owner of the NHL's Los Angeles Kings, operates a total of three franchises.

${ }^{109}$ This structure also raises the danger that a single investor-operator may attempt to load one of her teams with all of her best players. As a result, the power of the MLS Commissioner to block trades (a power each Commissioner also enjoys in the traditional league model) is especially important in maintaining a competitive balance throughout the league. See id. (explaining that the MLS Commissioner is "a final check and balance' on any owner attempting a shady trade between [her] teams"). Even without this safeguard, it is unlikely that the benefits an owner would accrue from creating a "loaded" team would outweigh the losses the owner would suffer from the reduced competitiveness of her other teams. 
for direct harm to the operator's other intraleague interests. ${ }^{110}$ In addition, MLS still operates two teams, which further weighs against the existence of significant intraleague competition. ${ }^{111}$ Thus, the fortunes of a single MLS team are so inextricably linked to the success of all the other teams that any argument emphasizing a diversity of interests among MLS teams seems extremely far-fetched.

\section{Fraser v. MLS: The Players' Claims}

The league practices at issue in Fraser concern MLS's restraints on its teams' ability to acquire players. In this area of league operations, MLS has retained a system very close to the more pure single entity model originally envisioned by Rothenberg. Once an investoroperator decides which players she would like to acquire, MLS negotiates a contract with the player. The terms of the agreement are subject to the league's salary cap and any restraints on player movement, after the acceptance of which the player becomes an employee of the league, rather than of the "allocated" team. ${ }^{112}$ The players allege that MLS's entire system of player restraints violates the antitrust laws. First, they argue, the salary cap, the centralized player allocation system, and the standard reserve clause in every player contract unreasonably restrict the labor market for professional soccer players in the United States by preventing MLS teams from competing against each other for the services of individual players. ${ }^{113}$ Second, the standard MLS player contract unlawfully restricts the players' ability to license their names and images. ${ }^{114}$ Third, the system of transfer fees promulgated by the sport's International Governing Body, FIFA, and enforced by the United States Soccer Federation and MLS, violates the antitrust laws by restricting players' ability to seek employment in

${ }^{110}$ See id. ("[T] $]$ he idea is ... successful businessmen won't abuse their multipleteam ownerships and risk undermining the league's credibility because, ultimately, they're business partners rather than competitors.").

${ }^{\prime \prime}$ See Jill R. Dorson, Clash Swept Up by Kraft Group: San Jose Club Sold After Rothenberg Deal Falls Through, S.F. EXAMINER, Nov. 19, 1998, at D2 (discussing MLS's current ownership situation).

"12 See WEILER \& ROBERTS, supra note 5, at 496-97 (discussing MLS's restrictions on player contracts).

${ }_{113}$ See Sarbjit Singh, Welcome to the Club: Upstart Major League Soccer Gets Sued, 6 SPORTS LAW. J. 217, 229-30 (1999) (discussing players' claims of antitrust violations).

${ }^{114}$ See id. at 230 (noting the players' claim that "[t]he MLS standard player agreement denies players a fair share of group licensing rights"). 
other leagues. ${ }^{115}$

\section{Fraser v. MLS: Assessing the Arguments}

In assessing the applicability to MLS of the concerted action requirement of section 1, there are several arguments the Fraser court is likely to consider.

\section{Copperweld Is Controlling}

MLS can argue that Fraser is factually indistinguishable from, and therefore directly controlled by, Copperweld's bright-line rule. As MLS and its shareholders wholly own the franchises, their intracorporate decisions, or league rules, cannot be deemed concerted action for section 1 purposes, and therefore are not subject to section 1 liability. MLS can even argue that its organization is a more pure single entity than the parent corporation and its wholly owned subsidiary in Copperweld. ${ }^{116}$ Under this view, MLS's franchises are not subsidiaries of the league, but more like "plants" where the corporation outputs its product.

\section{2. "Form vs. Reality" Analysis}

The court may decide, however, that the result in Copperweld is not directly controlling. In that case, the players can argue that the rationale of Copperweld demands a finding of concerted action. Copperweld emphasizes that the concerted action requirement directs courts to look at the economic reality, rather than the form, of the business association. ${ }^{117}$ Permitting MLS to escape section 1 liability similarly values form over economic reality. From this perspective, the single entity league has the same purpose, and produces the same basic product, as the traditionally organized leagues, and therefore should receive the same treatment under the antitrust laws. The competition

${ }^{115}$ See id. (noting the players' transfer fee claim). The transfer fee claims concern MLS's agreements with another economic entity, FIFA, and thus will not be affected by MLS's single entity argument.

${ }^{116}$ See Copperweld Corp. v. Independence Tube Corp., 467 U.S. 752, 756 (1984) (recounting the Copperweld Corporation's transfer of the Regal Company's assets into a subsidiary corporation, Regal Tube). After all, MLS consists of only one corporation, not two, as was the case in Copperweld.

${ }^{117}$ In fact, the Court repealed the intra-enterprise conspiracy doctrine in Copperweld precisely because it "looks to the form of an enterprise's structure and ignores the reality." Id. at 772. 
for coaches and other team personnel among MLS franchises is just like the off-field intraleague competition in the traditional leagues that the First Circuit emphasized in Sullivan. ${ }^{118}$

In addition, the nature of the special class of stock owned by the investor-operators creates incentives for each operator to compete at the expense of fellow shareholders. The investor-operators keep 50\% of the ticket sales, local broadcast, and local sponsorship revenue generated by their respective teams, and thus have divergent economic interests. ${ }^{119}$ Furthermore, should the investor-operator choose to sell her stock, the stock's value will reflect her team's competitive success. A winning team is likely to encourage greater attendance as well as generate additional revenue by hosting playoff games. Teams with a larger fan base and a healthy balance sheet will appreciate in value as compared to less successful clubs with smaller followings. Although the financial health of the league as a whole may be as, if not more, important than the prospects of an individual franchise, the on-field success or failure of a particular investor-operator's team affects the return on her investment. This economic reality creates additional incentives for the investor-operator to compete at the expense of the rest of the league.

The players' position is problematic, however, in several respects. First, MLS can dispute the players' characterization of "economic reality." The investor-operators that the players would perceive as independent economic actors are merely shareholders in the MLS corporation. It would be unthinkable in another context for a court to find concerted action through the actions of the shareholders of a single corporation. As the Seventh Circuit noted in WGN, simply because a large corporation like GM may have employees or shareholders with disparate interests does not mandate characterizing GM as something other than a single entity. ${ }^{120}$ The fact that the interests of shareholders may diverge under certain circumstances is clearly insufficient to warrant a finding of concerted action.

Second, the players' argument is also questionable because courts addressing the single entity question with respect to traditional leagues have found that the form of a sports league (an association of

\footnotetext{
${ }^{118}$ See supra notes $65-68$ and accompanying text (discussing Sullivan).

${ }^{119}$ See Singh, supra note 113, at 231 (describing the allocation of MLS revenues).

${ }^{120}$ See Chicago Prof'l Sports Ltd. Partnership v. NBA, 95 F.3d 593, 598 (7th Cir. 1996) ("WGN") ("Conflicts are endemic in any multi-stage firm . .. but they do not imply that these large firms must justify all of their acts under the Rule of Reason.").
} 
independently owned businesses) is its economic reality. ${ }^{121}$ The fact that the member clubs are independently owned and compete in some respects has been more persuasive than league arguments emphasizing the degree of cooperation undertaken by the member clubs. By this reasoning, Copperweld could actually be distinguished from Fraser (to MLS's benefit) because a sports league's unique qualities dictate that its form does matter, and is in fact the defining aspect of its economic nature. In finding insufficient evidence that the independently owned franchises acted as a single entity, the court rejected arguments concluding that form was irrelevant. ${ }^{122}$ Given this precedent, the Fraser court may be required to accept a sports league's form as indicative of its status as a single economic entity. Just as the court in Sullivan refused to look past the divergent interests created by independent club ownership, the Fraser court could find that the lack of independent owners is dispositive evidence of a unitary actor. To find otherwise would seem inconsistent with Sullivan, which, as a First Circuit opinion, is binding precedent for the District of Massachusetts Fraser court.

Finally, the players' position is problematic because the Copperweld court championed the right of business associations to organize themselves as they deem appropriate: "[A] business enterprise should be free to structure itself in ways that serve efficiency of control ...." ${ }^{223}$ The single entity structure allows MLS numerous efficiencies. ${ }^{124}$ MLS's freedom to self-organize would be compromised significantly if courts were free to ignore how a business chose to organize itself, opting instead to characterize a business as something other than its chosen form.

\section{Following WGN: Distinguishing MLS's Operations}

As an alternative to the "form vs. economic reality" argument, the MLS players can use the WGN opinion to distinguish certain aspects of MLS's operations from its relations with its players, the practices at is-

${ }^{121}$ See Sullivan v. NFL, 34 F.3d 1091, 1099 (1st Cir. 1994) (holding that because "NFL member clubs compete in several ways off the field," they could not be viewed as a single entity); Los Angeles Mem'l Coliseum Comm'n v. NFL, 726 F.2d 1381, 1389 (9th Cir. 1984) ("Raiders") (finding that the clubs were "separate business entities").

${ }^{122}$ See Sullivan, 34 F.3d at 1099 (finding that NFL teams have divergent interests).

${ }_{123}$ Copperweld Corp. v. Independence Tube Corp., 467 U.S. 752, 773 (1984).

124 See Lebowitz, supra note 97, at IF (noting the advantages of a single entity league, including controlling player costs, greater leverage in negotiating broadcasting contracts, and coordinated marketing strategies that eliminate the problem of ambush marketing). 
sue in Fraser. According to the Seventh Circuit, it is perfectly permissible to treat a traditionally organized league as a single entity in some respects and as a joint venture in others. ${ }^{125}$ Under this view, even if MLS is regarded as a single entity in some aspects of its operations, such as national television and marketing deals, and franchise relocation and expansion, it should still be treated as a joint venture in the player market. The nature of a sports league is such that individual teams will always compete with one another in the player market. In order to achieve on-field competitive success, teams must make themselves attractive as potential employers to players both within and outside of the league. Although MLS is technically responsible for negotiating player salaries and signing the players to employment contracts, ${ }^{126}$ it is really the demand of the individual teams for particular players that triggers league negotiations with those players. The league, therefore, merely acts as an agent for the teams by handling contract negotiations. Likewise, in the traditional leagues, the commissioner's office must approve all contracts and trades between teams to ensure that the transactions comply with league rules. This rule, however, does not render the traditional leagues single entities.

The end result of these labor practices, the Fraser plaintiffs can argue, is that MLS fails both the First Circuit's and the Eighth Circuit's "unity of interests" standards, articulated in Sullivan ${ }^{227}$ and Mt. Pleas$a n t,{ }^{128}$ respectively, as well as the Seventh Circuit's "depriving the marketplace of independent decision-makers" test, articulated in WGN. ${ }^{129}$ The competition between teams for players violates the "unity of interests" standard because teams are pursuing disparate interests as they attempt to attract the best players. MLS also fails the Seventh Circuit's test because the artificial market constraints imposed by MLS greatly reduce the autonomy of the individual decision-makers in the players' market. The market for professional soccer players' services in the United States would surely benefit from the removal of these restraints.

MLS can respond to the players' labor market argument by distinguishing the Seventh Circuit's decision in WGN. First and foremost, the WGN holding applies to traditional sports leagues, and not to

${ }^{125}$ See WGN, 95 F.3d at 600 ("[T] he ability of sports teams to agree on a TV contract need not imply an ability to set wages for players.").

${ }_{127}^{126}$ See supra text accompanying notes 100-107 (discussing MLS's structure).

${ }^{127}$ Sullivan, 34 F.3d at 1099.

${ }^{123}$ City of Mt. Pleasant v. Associated Elec. Coop., Inc., 838 F.2d 268, 27477 (8th Cir. 1988).

${ }^{120}$ WGN, 95 F.3d at 598-99. 
leagues organized as single corporations. If, instead, WGN is viewed as directly relevant, MLS can argue that the holding supports its argument. WGN directs courts to scrutinize carefully the nature and form of each challenged aspect of the sports league's practices. ${ }^{130}$ When MLS reorganized itself into a less "pure" single entity, it did not alter its system of negotiating all contracts with players and retaining complete control over assigning players to a particular team. Even though investor-operators may request that the league sign a particular player, the league's control over the process remains so tight that intraleague competition for players is muted. Although this reality has profoundly anticompetitive effects in the player market, those effects are not relevant for determining whether concerted action exists. ${ }^{131}$

MLS's player acquisition system is directly analogous to a corporation that solicits advice from its plant managers before hiring its employees. If these plant managers receive potentially lucrative compensation bonuses when their plants outperform the other company plants (as MLS's investor-operators do if their special class of stock appreciates), the plant managers obviously would lobby the central hiring office to secure the best employees for a particular plant. It is also possible that the skills of a particular prospective employee (like that of a superstar athlete) are so exceptional that the plant managers would be willing to offer the prospective employee significantly more compensation than the company is willing to pay. The company's refusal to pay the employee more than what the company budgeted, however, does not in itself create an antitrust violation. The prospective employees could argue that the company is "depriving the marketplace of independent centers of decision-making" by not allowing the individual plant managers to pay what they believe the employee is worth. Even so, the courts would likely honor the single corporate form that the company had adopted and refrain from finding concerted action, despite the anticompetitive effect of the company's practices. MLS's control over the supply of players entering the league is no different from the company's control over employees in this corporate example.

The argument against the existence of concerted action is further strengthened by the fact that more than half of MLS's teams are

${ }^{130}$ See WGN, 95 F.3d at 600 ("[I]t is essential to investigate [a league's] organization and ask Copperwelds functional question one league at a time-and perhaps one facet of a league at a time....").

${ }^{131}$ The anticompetitive effects would of course become relevant if concerted action was found. 
owned by investor-operators who own multiple teams. ${ }^{132}$ Aside from the fact that the league would block an investor-operator from doing so, any efforts by a particular investor-operator controlling multiple teams to "buy a championship" for one of her teams would inevitably damage her investment in her other team(s). Thus, for a majority of teams, reckless spending on players would be counterproductive to the interests of the free-spending investor-operator, not just the league as a whole.

The weight of the arguments favors MLS's position. Substituting the single entity sports league for the traditional model changes such dispositive characteristics that it becomes illogical to treat a league like MLS as a collection of economic actors competing in any meaningful economic sense. Therefore, section 1 of the Sherman Act should not apply to MLS.

\section{THE POSSIBILITY OF SECTION 2 LIABILITY}

A legal victory for MLS on the single entity question would only result in the dismissal of the MLS players' section 1 claim. The players could still pursue a claim under section 2 of the Sherman Act because section 2 does not have a concerted action requirement.

Section 2 prohibits monopolization and attempted monopolization by a single economic actor. ${ }^{133}$ The players could allege that MLS's practices constitute an abuse of the league's monopoly power in the market for soccer players. Generally, players who have brought antitrust claims against leagues have not used section 2 and proving a section 2 violation has, in practice, been far more difficult than making a successful section 1 claim. $^{134}$

To make a successful section 2 claim, the MLS players would first

${ }^{132}$ See supra note 108 and accompanying text (noting that several MLS owners operate more than one MLS team).

${ }^{13 s}$ See 15 U.S.C. $\S 2$ (1994) ("Every person who shall monopolize, or attempt to monopolize, or combine or conspire with any other person or persons, to monopolize any part of the trade or commerce among the several States ... shall be deemed guilty of a felony....").

${ }^{194}$ See Jacobs, supra note 30 , at 28 n.12 ("[C] hallenges to league activities under section 2 have been infrequent and, for a variety of reasons, unsuccessful."). Section 2 cases generally have featured other leagues or franchises as plaintiffs. See, e.g., United States Football League v. NFL, 842 F.2d 1335, 1341-42 (2d Cir. 1988) (upholding the jury's finding that the defendant was guilty of section 2 antitrust violations but liable for only one dollar); Mid-South Grizzlies v. NFL, 720 F.2d 772, 788 (3d Cir. 1983) (upholding the NFL's refusal to admit a former World Football League franchise into the NFL); American Football League v. NFL, 323 F.2d 124, 134 (4th Cir. 1963) (failing to find that the NFL monopolized the relevant market). 
have to show that the relevant product and geographic market is the labor market for elite professional soccer players in the United States. ${ }^{135}$ Assuming arguendo that the players successfully characterize this labor market as the relevant product market, ${ }^{136}$ they will likely have a much more difficult time proving that the relevant geographic market is the United States. The players would have to prove that if a hypothetical monopolist soccer league in the United States were to impose wage restrictions that depressed wages by a small but significant amount (usually 5-10\%), players would have no option but to sign with the monopolist league. ${ }^{137}$ This argument ignores the fact that there are many other professional soccer leagues around the world that offer comparable (and in many cases, superior) competition and compensation. Although players may prefer to play in an American league for a variety of reasons, the court may view the availability of close substitutes to an American league as reason to designate the world-wide market as the relevant market for the services of professional soccer players. Because MLS is only one of many top leagues scattered throughout the world, it falls far short of the $50 \%$ minimum market share generally required to prove market power. ${ }^{138}$ This failure to prove market power would result in dismissal of the section 2 claim against MLS. ${ }^{139}$

${ }^{135}$ See United States v. Grinnell Corp., 384 U.S. 563, 570-71 (1966) ("The offense of monopoly under $\$ 2$ of the Sherman Act has two elements: (1) the possession of monopoly power in the relevant market and (2) the willful acquisition or maintenance of that power as distinguished from growth or development as a consequence of a superior product, business acumen, or historic accident.").

${ }^{136}$ The NFL's repeated attempts to argue that it "faces market competition" from other professional sports leagues and other forms of entertainment have been rejected. WEILER \& ROBERTS, supra note 5, at 603. It is also worth noting that there is considerable scholarly debate as to whether the antitrust laws (either section 1 or section 2) apply to labor markets at all. See id. at 152-53 (noting that because "monopsony" power held by the purchaser may merely induce a wealth transfer, and actually enhance consumer welfare, a buyer's control of the labor market may not be subject to antitrust scrutiny).

${ }^{137}$ See United States v. Engelhard Corp., 126 F.3d 1302, 1304 (11th Cir. 1997) (describing, but not adopting, the Department of Justice's test for determining the relevant product market).

${ }^{135}$ See Domed Stadium Hotel, Inc. v. Holiday Inns, Inc., 732 F.2d 480, 489 (5th Cir. 1984) ("Supreme Court cases ... suggest that absent special circumstances, a defendant must have a market share of at least fifty percent before he can be guilty of monopolization.").

${ }^{139}$ Even if the players' proffered market definition was accepted by the court, they still might have difficulty proving that MLS abused its market power. The standard for assessing what constitutes an abuse of monopoly power is the subject of considerable disagreement. Some circuits have adopted an extremely pro-defendant test that requires the plaintiff to prove that the sole purpose of the conduct at issue was to harm 
The problems of proving both the existence of market power and the abuse of that power highlight some of the challenges involved in pursuing a section 2 claim, especially against MLS. These difficulties only further accentuate the importance of the single entity questionshould MLS prevail on that issue, it likely will be extremely well insulated from any antitrust challenges by its players. ${ }^{140}$

\section{A Plan to Reorganize the Traditional Leagues}

New sports leagues need not be the only leagues to enjoy the benefits of the single entity structure. Should MLS succeed in arguing that it is a single entity for antitrust purposes, as this Comment predicts, the traditional leagues should reorganize themselves along the MLS (or some similar) corporate model. ${ }^{141}$ The reorganization plan set forth in this section modifies a plan proposed by Jeffrey $A$. Rosen-

the defendant's competition. See United States v. Microsoft Corp., 147 F.3d 935, 950 (D.C. Cir. 1998) (finding that the defendant's ability to "ascrib[e] facially plausible benefits to its integrated design" was sufficient to meet its burden of demonstrating the lack of a violation of an antitrust-based consent decree); Berkey Photo, Inc. v. Eastman Kodak Co., 603 F.2d 263, 276 (2d Cir. 1979) (holding that a monopolist may seek competitive advantage in a different market as long as it is merely "reaping the competitive rewards attributable to its efficient size"). The Ninth Circuit, on the other hand, allows a showing of "unreasonably exclusionary" conduct, which suggests more of a balancing approach. See Image Technical Servs., Inc. v. Eastman Kodak Co., 125 F.3d 1195, 1209 (9th Cir. 1997) (affirming a jury instruction that declared "unnecessarily exclu[sionary]" conduct by a monopolist illegal).

${ }^{140}$ The players and other parties will be able to sue under section 1, however, for agreements MLS makes with third parties that violate the Rule of Reason. For example, the Fraser plaintiffs have challenged the MLS-FIFA arrangement that requires outside leagues to pay transfer fees for the rights to all MLS players, including those whose contracts with MLS have expired. MLS moved for summary judgment on the grounds that it has not yet enforced its right to demand a transfer fee. The judge, however, denied the motion. See Fraser v. MLS, 7 F. Supp. 2d 73, 75 (D. Mass. 1998) (refusing to rule that the transfer fee question was moot even though MLS had never requested a transfer fee).

${ }^{141}$ The leagues may also want to wait for the Supreme Court to resolve the circuit split concerning the appropriate standard of liability for section 2 of the Sherman Act. See supra note 139 (discussing the circuit split). If the Court adopts a defendantfriendly standard similar to the Second Circuit's Berkey Photo test, it will provide additional incentive for the leagues to reorganize. 603 F.2d at 276. Conversely, if the Court were to adopt a more plaintiff-friendly balancing test, like the Ninth Circuit's "unreasonably exclusionary" standard in Image Technical Services, the difference between the standards for section 1 and section 2 liability would be less significant. 122 F.3d at 1209. This would decrease the significance of the inapplicability of section 1 to the reorganized league. Even if the Supreme Court adopts a plaintiff-friendly standard, however, a section 2 plaintiff would still have to prove that the defendant league possessed monopoly power, which would be very difficult in many circumstances. See discussion supra Part III (explaining the difficulties involved in making a successful section 2 claim). 
thal in The Football Answer to the Baseball Problem: Can Revenue Sharing Work ${ }^{42}$ in which he attempts to solve an entirely different problem plaguing one of the traditional leagues: the large disparities in the economic strength of Major League Baseball's franchises. ${ }^{143}$

\section{A. Big League Perestroika}

To begin, I propose that each of the traditional leagues change their status from an unincorporated association to a limited liability corporation. The "corporate league" would then buy its franchises from the owners for the franchises' value, as determined by an independent appraiser. ${ }^{144}$ Any owner who prefers not to continue under the new corporate system would receive cash for her franchise. Participating owners, like MLS investor-operators, would receive two

142 Jeffrey A. Rosenthal, The Football Answer to the Baseball Problem: Can Revenue Sharing Work?, 5 SETON HALLJ. SPORT LAW 419 (1995).

${ }_{143}$ Rosenthal's proposal included the following:

(1) Have the league "purchase" every team for its appraised value.

(2) "Sell" each team back to its original owner at the estimated new value after calculating the impact of revenue sharing. For owners that choose not to re-purchase their teams, solicit outside bids.

(3) Allow teams that owe money (due to the increased value of their team) to finance the purchase through future income (but keep the period of time relatively short to avoid draining available resources over a long time).

(4) Assume central league control for negotiating all local broadcasting contracts. Attempt to cross-market by permitting multiple games to be broadcasted into each market, particularly during the September pennant races.

(5) Share all national and local broadcasting revenues equally.

(6) Divide gate receipts unequally - a split of approximately 67-33 seems fair (33\% should go to the visitor, not the league; this rewards good teams who are in demand in other cities). This will ensure that a sufficient incentive to win remains.

(7) Attempt to negotiate some form of revenue sharing with players to avoid potentially decreasing salaries and other potential externalities as discussed herein.

(8) Ignore fixed income such as stadium revenues for now, unless many owners choose to forsake profit-maximizing behavior and spend this revenue to the disadvantage of teams with less favorable lease arrangements.

Id. at $466-67$.

${ }_{144}$ As described in Rosenthal's plan, the franchise values could be adjusted to account for anticipated changes in particular league rules. For example, baseball might choose to adopt increased revenue sharing measures, which Rosenthal deemed essential to the game's economic stability. See id. at 423-28 (discussing the need for revenue sharing). 
kinds of stock in return for ownership rights to their respective teams. One class of stock would provide for the traditional voting rights within the league that all franchise owners currently enjoy, as well as a share of the league's profits. The other class of stock would grant control of the day-to-day operations of the individual franchises to their previous owners and allow the owners to sell this stock to outside bidders. The franchises themselves could be owned directly by the incorporated league or exist as subsidiaries wholly owned by the parent league corporation, similar to the defendants' arrangement in Copperweld $^{145}$

The advantages of the corporate league would be manifold. First and foremost, the league would not face section 1 liability. Because almost every aspect of traditional league operations has been challenged under section 1, leagues necessarily are constrained in adopting new rules and entering into new arrangements by the constant threat (if not the certainty) of a section 1 challenge. By removing section 1 liability, the leagues would not have to overcome such barriers, and would also avoid the expense of litigating many lawsuits. Although it is certainly true that claims could still be brought under section 2, the difficulty of making such a claim successful will likely deter many suits. The corporate league would also enjoy increased bargaining leverage over its players, increased sponsorship opportunities, more efficient decision-making, and improved economies of scale. ${ }^{146}$

\section{B. Potential Problems with the Proposal}

The proposed reorganization is admittedly a radical measure that would fundamentally change the basic structure of each league. The reorganization would probably raise some significant, but not insurmountable, problems. The advantages of the corporate league are so sizeable, however, that a close examination of the problems facing reorganization should not overshadow the long term benefits that the corporate league would enjoy. As one source noted, "[i]f [NFL] Commissioner Paul Tagliabue could convert the NFL to a single entity, he'd do it tomorrow." 147

Some team owners may be strongly opposed to such a plan because they derive value from the status their control of a team brings in the community and amongst other wealthy people. Not surpris-

\footnotetext{
${ }^{145}$ Copperweld Corp. v. Independence Tube Corp., 467 U.S. 752, 756 (1984).

${ }^{145}$ See supra Part II.A (discussing the benefits of single entity leagues).

${ }^{17}$ Lebowitz, supra note 97 , at $1 \mathrm{~F}$.
} 
ingly, MLS had great difficulties attracting investors under its original plan, which did not provide for the investors to be associated with a particular team. ${ }^{148}$ The plan essentially would have turned the investors into anonymous stockholders. MLS quickly realized its mistake and created a second class of investor-operator stock, which allows an owner to exercise control over a particular team, and thus achieve the public visibility that was absent in the league's original plan. ${ }^{149}$ Owners in other leagues may also fear that they will lose the ability to run their teams without interference, as well as the community recognition that has made sports teams such valuable commodities. By issuing the second class of investor-operator stock, however, the reorganized leagues can ensure that the owners retain the value they derive from the status value of team ownership. Owners would also appreciate the fact that the corporate league would be more profitable due to the economic advantages gained through the change in structure. ${ }^{150}$ Greater profitability translates into both higher dividends and higher valuations of the individual teams, which should cause the second class of stock held by the owners to appreciate.

On the other hand, the traditional model may provide certain tax advantages over the single entity model since owners can deduct the operating losses of their individual franchises. ${ }^{151}$ The projected loss of tax benefits, however, can be figured into the original appraised price of the franchise. Furthermore, other owners whose franchises regularly recognized annual operating profits may realize tax savings under the single entity plan. Thus, it is likely that any tax considerations can be handled as an internal league matter, with some owners using their gains to compensate others for their losses. Moreover, the dwindling breed of owners who have held franchises for a long time, do not have sizeable holdings in other businesses, and are concerned chiefly with estate taxes also should not be negatively affected since the sale of the teams to the league in exchange for stock would have no effect on estate taxes. Thus, tax concerns should not prove to be a significant obstacle to league reorganization.

The players' union, fearing the loss of a section 1 claim as a bargaining chip with the league, may file an unfair labor practice charge

${ }^{148}$ See WEIIER \& ROBERTS, supra note 5, at 495 (discussing the problems with the original plan).

${ }_{149}$ See id. at 496.

${ }^{150}$ See supra Part II.A (discussing the advantages of the corporate structure of the league).

i51 See I.R.C. $§ 165$ (a) (1999) (allowing a deduction for "any loss sustained during the taxable year"). 
claiming that the reorganization must be negotiated with the union. Although employers are obligated to bargain with unions over changes "with respect to 'wages, hours, and other terms and conditions of employment,"'152 certain aspects of a firm's business are reserved to the discretion of the firm's management and do not require bargaining with unions. This includes the manner by which a firm chooses to organize itself. ${ }^{153}$ Therefore, a league would not have to bargain with the union over its decision to reorganize itself.

Additionally, the players or another party, such as the federal government, may also attempt to block the reorganization through antitrust law. The single entity question will probably not become a settled matter of law following the disposition of Fraser $v$. MLS, unless the Supreme Court renders a judgment on the matter. Until that time, a reorganized league would have to accept a degree of uncertainty that it may not be deemed a single entity for section 1 purposes.

Concerns about a section 2 claim may limit some of the benefits reorganization may provide. Section 2 jurisprudence, especially regarding labor claims against employers, is so unsettled that the leagues may be reluctant to risk incurring treble damages by adopting new restraints in the player market. ${ }^{154}$ For section 2 purposes, the traditional leagues are unlike MLS in that each one is the preeminent league of its kind in the world. The NFL, for example, has no serious competition from other football leagues in terms of both the quality of play and the level of compensation for its athletes. NFL players pursuing a section 2 claim should be able to define the relevant market as that for elite professional football players in the United States, where the NFL has a complete monopoly. ${ }^{155}$ But even if the players are successful in showing a single entity league has market power, the

${ }^{152}$ Fibreboard Paper Prods. Corp. v. NLRB, 379 U.S. 203, 210 (1964) (quoting the National Labor Relations Act).

${ }^{153}$ See NLRB v. International Harvester Co., 618 F.2d 85, 87 (9th Cir. 1980) ("Management decisions that fundamentally alter the direction of an enterprise . . . generally are not considered decisions concerning terms and conditions of employment and are not mandatory subjects of bargaining." (citing Fibreboard Paper Prods. Corp., 379 U.S. at 223 (Stewart, J., concurring))). dards).

${ }^{154}$ See supra notes 139, 141 (discussing the circuit split concerning section 2 stan-

${ }^{155}$ The other major leagues-the NHL, the NBA, and MLB-might be able to argue that international leagues are viable substitutes in the market for each league's players, but such an argument is unlikely to be successful given the sizable gap in standards of play and compensation between these North American-based leagues and other leagues around the world. 
task of proving abuse of market power still remains a difficult one. ${ }^{156}$

Finally, the provisions of section 7 of the Clayton Act might be used to attack a league's reorganization in a suit brought by the federal government or the players. Section 7 provides that "[n]o person ... shall acquire the whole or any part of the assets of another person engaged also in commerce ... where ... the effect of such acquisition may be substantially to lessen competition, or to tend to create a monopoly." ${ }^{157}$ A union making a section 7 claim would attempt to characterize the league's action as a merger, rather than a reorganization, which substantially lessens competition in the player market. The union's merger claims would be weighed against the familiar (and heretofore unsuccessful) league claims that it is a single entity, but also, perhaps more significantly, the Copperweld Court's emphasis on the freedom of business enterprises to organize themselves as they see fit. ${ }^{158}$ In comparison to the traditional league model, the single entity structure features significant efficiencies which, according to Copperweld, a business enterprise should be able to realize, free from government interference. ${ }^{159}$ A section 7 challenge, therefore, is by no means an insurmountable obstacle for traditional leagues seeking to enjoy the advantages of a single entity structure.

\section{CONCLUSION}

The advent of the single entity sports league may prove to be a vitally important event for the future of professional sports leagues. Although the demise of the American Basketball League ${ }^{160}$ shows that single entity leagues are by no means exempt from the cruel economic realities of competition in the sports and entertainment marketplace, the single entity form does provide a structure in which nascent sports leagues may flourish more readily with proper marketing of its product. Surely a single entity league will be able to avoid some

${ }^{156}$ See supra note 139 (describing the debate over the appropriate standard for determining abuse of monopoly power).

${ }^{157} 15$ U.S.C. $\$ 18$ (1994).

${ }^{153}$ See Copperweld Corp. v. Independence Tube Corp., 467 U.S. 752, 773 (1984) ( $[\mathrm{A}]$ business enterprise should be free to structure itself in ways that serve efficiency of control, economy of operations, and other factors dictated by business judgment without increasing its exposure to antitrust liability.").

${ }^{159}$ See id. at 772-73 (asserting that a corporation should be able to restructure and reorganize its operations in order to best serve the corporation's interests, without raising assumptions of illegitimate motives).

${ }^{160}$ See supra note 107 (describing the structure and subsequent bankruptcy of the American Basketball League). 
of the problems confronted by upstart leagues such as the North American Soccer League and the United States Football League. ${ }^{161}$ Both of those leagues were driven into bankruptcy in part by the profligate ways of its teams in the biggest markets, which relegated smaller market teams to second class status and diminished the on-field product. $^{162}$ The single entity structure provides a solution to this problem and thus should make the creation of new sports ventures possible. As a general policy matter, the single entity form is therefore decidedly pro-competitive in its effects, and actually encourages the creation of the labor markets it may subsequently constrain.

The reorganization of the traditional leagues proposed in this Comment remains strictly a long term possibility. Of course, a favorable outcome for MLS in Fraser is necessary. Nevertheless, the leagues should begin exploring the possibility of reorganization. The continual threat of section 1 claims has hampered leagues' efforts to maximize their bargaining leverage with players' unions and exposed the league to protracted and burdensome litigation with players, owners, and other leagues. The removal of the section 1 threat and the potential that the single entity model holds for controlling player costs provide powerful incentives for leagues to follow MLS's lead and adopt single entity structures.

${ }^{161}$ See Lebowitz, supra note 97, at IF (contrasting MLS with other upstart leagues, including the NASL and the USFL).

${ }^{162}$ See id. ("The NASL situation wasn't much different than the financial disparities between franchises that killed the United States Football League.... "). 
